ks. prof. dr hab. Władysław Majkowski

AKADEMIA POLONIJNA W CZĘSTOCHOWIE

\title{
Wybrane aspekty ubóstwa polskich rodzin
}

\section{Wstęp}

Niewiele jest zdarzeń na świecie, które stają się nagle, na zasadzie deus ex machina. Odwrotnie: prawie wszystkie mają swoją dłuższą lub krótszą historię, swoich protagonistów, a nade wszystko swoje uwarunkowania. Nawet gdy któryś z tych czynników nie jawi się wystarczająco klarownie, to i tak nie znaczy to, że nie zaistniał i nie miał swojego wpływu na końcowy efekt.

Nie inaczej jest też $\mathrm{z}$ materialną sytuacją polskich rodzin na początku XXI wieku. Jest ona wypadkową wielu czynników, które złożyły się na ich obecny stan. Jedne są oddalone w czasie, podczas gdy inne są czasowo bliskie; jedne mają charakter społeczny, inne są natury ekonomicznej; wszystkie jednak mają swoje odniesienie do systemów ekonomicznych, w ramach których sytuacja ta nabierała konkretnych kształtów.

Mając ten fakt na uwadze, nie sposób nie wspomnieć uwarunkowań tak historycznych, jak i politycznych minionego wieku, które kształtowały środowisko życia i funkcjonowania polskich rodzin, a które złożyły się na całokształt uwarunkowań współczesnej rodziny polskiej, a jej sytuacji ekonomicznej w szczególności. Są nimi: zniszczenia wojenne, niewydolny komunistyczny system oraz zawirowania transformacji systemowej. Pewnie byłoby trudno, a wręcz 
jest rzeczą niemożliwą określić kwantytatywnie siłę każdego z nich, ale ich przyczynek jest nie do zakwestionowania.

\section{Historyczne uwarunkowania}

Polska, jaką zastała II wojna światowa, była krajem biednym, rolniczym, ledwie co dźwigającym się ze straszliwych zniszczeń I wojny światowej. Opinii tej nie zmienia fakt wysiłków podejmowanych $w$ celu dokonania koniecznych zmian, takich jak budowa portu w Gdyni czy Centralnego Okręgu Przemysłowego. II wojna światowa nie tylko zatrzymała proces industrializacji, ale spowodowała ogromne straty we wszystkich zasobach kraju. Oznacza to, że podejmowane działania okresu 18 lat wolności nie tylko zostały zatrzymane, ale ich osiągnięcia w dużej mierze zostały unicestwione.

Sytuacja ekonomiczna Polski po zakończeniu wojny była zatem wyjątkowo trudna. Do ekonomiczno-społecznego zapóźnienia doszły ogromne straty, jakie poniósł kraj- 38 proc. wszystkich swych zasobów. Straty w poszczególnych sektorach gospodarki były różne, ale we wszystkich bardzo wysokie: największe w sektorze transpor$\mathrm{tu}-62$ proc., 60 proc. w szkołach i naukowych instytucjach, w budynkach 50 proc., w rolnictwie wynosily 35 proc., w lasach -28 proc.; nadto Polska straciła 22 proc. populacji, w tym wielu uczonych, ludzi biznesu, wojskowych....

1 A. Bodnar, Economie, [w:] Pologne: realité et problems, ed. J. Leszno, Kraków 1966, s. 123. Podczas gdy nie mniej zniszczone przez działania wojenne Niemcy potrafiły się szybciej i sprawniej uporać ze zniszczeniami wojennymi, Polska nie radziła sobie z tym problemem bardzo długo. Powody tego były zasadniczo dwa: niemożliwość skorzystania z planu 
Po przejęciu władzy w Polsce komuniści podjęli reformę gospodarki na wzór sowiecki, nacjonalizując zakłady przemysłowe: kopalnie, fabryki, elektrownie, huty, koksownie, przemysł zbrojeniowy... oraz banki. Formalnie zostało to dokonane dekretem $\mathrm{z}$ dnia 3 stycznia 1946 roku. Akt ten był jedynie zalegalizowaniem zaistniałej już wcześniej sytuacji, a mianowicie przejęcia i zabezpieczania fabryk i zakładów przemysłowych wszelkiego rodzaju przez komitety fabryczne, w miarę jak posuwał się front, jeszcze na długo przed zakończeniem wojny. Tym sposobem wszystkie wielkie zakłady znalazły się pod kontrolą państwa, zanim jeszcze ukazał się sam dekret o nacjonalizacji kluczowych gałęzi przemysłu. Odtąd komunistyczna doktryna miała rządzić gospodarką. Miała ją kształtować, wymyślać jej zasady i była powoływana na jego legitymizację i obronę w przypadku, gdyby komuś przyszło na myśl ją reformować, a tym bardziej usiłować zastąpić .

Wprowadzona przez komunistyczny reżim tak zwana reforma rolna pozbawiła własności ziemskiej jej bogatych właścicieli. Najpierw skonfiskowano posiadłości ziemskie obywateli niemieckich, obywateli polskich niemieckiego pochodzenia oraz tych, którzy w czasie okupacji współpracowali z okupantem. Nadto konfiskacie uległy też wszelkie dobra ziemskie, niezależnie kto był ich właścicielem, jeśli ich areał przekraczał w całości 100 ha lub 50 ha gruntów ornych. Tylko niewielka część skonfiskowanych posiadłości ziemskich została

Marshalla oraz niewydolny ekonomiczny system, narzucony Polsce przez sowiecką Rosję.

2 S. Kurowski, Doktrynalne uwarunkowania obecnego kryzysu gospodarczego PRL. Referat wygłoszony na konferencji Polskiego Towarzystwa Socjologicznego: Socjologiczne i ekonomiczne problemy gospodarki planowanej 12.05.1979. 
przeznaczona na uwłaszczenie małorolnych chłopów; w ogromnej większości na skonfiskowanych terenach stworzono kołchozy i państwowe gospodarstwa rolne. Tym sposobem, w niespełna dwa lata po przejęciu władzy przez komunistów, wszystkie sektory gospodarki znalazły się pod kontrolą państwa.

Zgodnie z założeniami ideologicznymi władze komunistyczne położyły szczególny nacisk na industrializację kraju. Miało się to dokonać w ramach trzyletniego planu (1947-1949). W ramach drugiego planu - sześcioletniego (1950-1955) zakładano rozbudowę na wzór sowiecki przemysłu ciężkiego. Przyjąwszy taką strategię, Polska zaczęła produkować okręty, lokomotywy, ciężkie maszyny, oprócz wszelkiego rodzaju sprzętu wojskowego. Natomiast bardzo małe środki przeznaczano na rozbudowę przemysłu lekkiego, co w krótkim czasie zaowocowało wszelkiego rodzaju brakami. Na rynku nie było podstawowych produktów potrzebnych w życiu codziennym.

Oczywistym następstwem industrializacji kraju była urbanizacja z dynamicznym wzrostem ludności miejskiej. Jeśli w 1946 roku stosunek ludności miejskiej do wiejskiej wynosił 0,51 przy ogólnej liczbie ludzi 23,6 mln, to w 1965 roku liczby mieszkańców miast i wsi zrównały się. Dziesięć lat później stosunek ten wyniósł już 1,25 na korzyść ludności miejskiej, by w 1985 roku osiągnąć wielkość $1,52^{3}$.

W następstwie takiej polityki udział przemysłu w dochodzie narodowym rósł bardzo szybko, dystansując sektor pierwszy. Świadczyły o tym wielkie inwestycje, których dokonano w tym sektorze. Nie tylko budowano nowe zakłady, ale rozbudowano juz istniejące (w liczbie 180). Z ogółu nakładów 20,9 proc. przeznaczono na rozbudowę

3 „Rocznik Statystyczny” 1992, s. 40. 
przemysłu hutniczego, paliwowego - 18 proc., maszynowego 17,4 proc. i chemicznego 12,5 proc. ${ }^{4}$. I tak: jeśli w 1951 roku udział $\mathrm{w}$ dochodzie narodowym przemysłu i rolnictwa był jednakowy, to do roku 1979 produkcja rolna wzrosła zaledwie o 100 proc., natomiast produkcja sektora drugiego powiększyła się o 1500 proc., czyli wzrosła 15 razy $^{5}$.

Przytoczone wielkości wskazują nie tyle na jakąś cudowną dynamikę sektora przemysłowego, ile raczej na nieefektywność produkcji gospodarstw rolnych kontrolowanych przez państwo. Wskazał na ten fakt Władysław Gomułka w swojej mowie w 1956 roku. Według przytoczonych przez pierwszego sekretarza danych, podczas gdy dyskryminowane prywatne gospodarstwa przynosily z hektara dochód 621,1 zł rocznie, kołchozy były w stanie wypracować 517,3 zł, to państwowe gospodarstwa zaledwie 393,7 zł. To właśnie ten stan rzeczy Gomułka nazwał „smutnym obrazem”.

Jednak ten „smutny obraz” polskiego rolnictwa przetrwał do 1989 roku, a nawet poza ten okres, aczkolwiek w nieco odmiennej formie. Władze komunistyczne wzrost produkcji zwykle określały w rocznych planach. Rzecz w tym, że te prawie nigdy nie były realizowane. Na przykład plan na rok 1969-1970 zakładał wzrost PKB o 5,8 proc., w tym 2,9 proc. w produkcji rolnej, I proc. w hodowli zwierząt. Taki wzrost okazał się jednak nierealny. Faktyczne wielkości wynosiły odpowiednio: 5,2 proc., 2,2, a w przypadku hodowli zwierząt nie

4 J. Szczepański, Zmiany społeczeństwa polskiego w procesie uprzemystowienia, Warszawa 1973, s. 217.

5 W. Majkowski, People's Poland: patterns of social inequality and conflict, Westport 1985, p. 32.

6 Gomulka's keynote speech, [w:] World communism: key documentary material, ed. S. Hook, New York 1962, s. 233-243. 


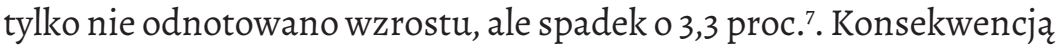
tego stanu rzeczy były braki na rynku, które wymusiły reglamentację podstawowych artykułów żywnościowych: mięsa, cukru, masła, a nawet alkoholu.

Rzecz jednak w tym, że nawet pod wpływem tych porażających danych „władze nie zarzuciły myśli o «socjalistycznej» przebudowie wsi, lecz nie odważyły się już na frontalny atak i proklamowanie kolektywizacji. [...] Przede wszystkim jeszcze przez kilka lat po 1956 r. utrzymywały - zredukowane jednak - dostawy obowiązkowe, ograbiające chłopską gospodarkę. Ze spółdzielni i kółek rolniczych usiłowały uczynić «dźwignię uspołecznienia» próbując w ten sposób stworzyć struktury stanowiące namiastkę, a może i przedsionek gospodarstw kolektywnych"8.

Powyższe braki nie były w żadnej mierze odosobnione. Jeszcze w latach 70. do rzeczy luksusowych zaliczano pralkę automatyczna, kolorowy telewizor, nie mówiąc o telefonie czy samochodzie. Taki stan rzecz czynił z Polski kraj zacofany i biedny nawet w porównaniu z wcale niebogatymi państwami. Dla przykładu: w 1976 roku na 1000 osób przypadało: we Włoszech 271 telefonów, w Hiszpanii239, w Stanach Zjednoczonych - 721, a w Polsce - zaledwie 189. Rok później na tę samą liczbę osób przypadało w Polsce 44 samochody (zwykle Fiaty 125 - popularnie zwane "maluchami”) - w Grecji 55, a w Hiszpanii $162^{10}$.

7 S. Markowski, Podstawowe zagadnienie NPG na 1970, „Przegląd Związkowy" 1969, nr 12, s. 4.

8 I. Ihnatowicz i in., Społeczeństwo polskie od X do XX wieku, Warszawa 1999, s. 696.

9 „Rocznik Statystyczny” 1979, s. 537.

10 „Rocznik Statystyczny” 1979, s. 539. 
Najbardziej dotkliwym brakiem był brak mieszkań. Również i w odniesieniu do tego działu gospodarki dane były przerażające. $\mathrm{Na}$ spółdzielcze mieszkanie trzeba było czekać 15 lat, a nierzadko nawet dłużej. Plany budowy mieszkań prawie nigdy nie były wykonywane, a to jeszcze bardziej wydłużało okres oczekiwania na mieszkanie.

Tę sytuację prof. Edward Lipiński w swoim liście otwartym do Edwarda Gierka nazwał rzeczywistymi i znacznymi obszarami nędzy w Polsce ${ }^{11}$. W rzeczy samej nie mogło być inaczej, ponieważ jak to wyakcentował Stefan Kurowski - „wtedy, kiedy dyktator jawnie ogłasza kolektywizację rolnictwa, choć prowadzi to do głodu i do niedożywienia całych pokoleń, kiedy wielkorządca czy minister skrycie dąży do pegeeryzacji, choć gotuje w ten sposób nieuchronny kryzys żywnościowy i obciąża gospodarkę swego kraju olbrzymimi kosztami, kiedy naczelnik gminy szykanuje indywidualnego rolnika, by go wyzuć z gospodarki, a potem nie sprzedaje tej ziemi innemu indywidualnemu rolnikowi, lecz przekazuje ją do kółka rolniczego, by tam leżała odłogiem. Kiedy inny wielkorządca narzuca skrajnie scentralizowany system zarządzania przemysłowi drobnemu i handlowi - wszyscy oni działają w myśl tej jednej zasady wiodącej, wszyscy stosują prymat polityki nad ekonomią, a wynikające stąd olbrzymie straty gospodarcze znoszą z lekkim sercem, gdyż posiadanie władzy politycznej zabezpiecza ich osobiście przed skutkami tego marnotrawstwa"12. W tym samym czasie elita władzy miała się dobrze, ciesząc się wszelkiego rodzaju przywilejami. Nic dziwnego zatem, że w społeczeństwie polskim coraz bardziej utrwalało się

11 E. Lipiński, List otwarty do Tow. E. Gierka, „Aneks” 1976, nr 12, s. 55.

12 S. Kurowski, Doktrynalne uwarunkowania obecnego kryzysu gospodarczego PRL, dz. cyt. 
przekonanie, że w Polsce warunki życia są nie tylko trudne, ale nawet nie do zniesienia, i że coś z tym trzeba zrobić. Bunt robotników doprowadził do powstania ruchu społecznego „Solidarność”, który wymusił zmiany polityczne i ekonomiczne.

\section{Trudna transformacja}

Chociaż za początek transformacji systemowej w Polsce uważa się rok 1989, to jednak jej historia i uwarunkowania są znacznie dłuższe. Konflikt strukturalny w Polsce pojawił się już w latach 50. - pomiędzy elitą władzy a klasą chłopów; protagonistami następnego konfliktu były klasa inteligencji i elita władzy - rok 1968, i wreszcie miał miejsce konflikt pomiędzy elitą władzy i robotnikami w latach 70 . i 80. Jednak podczas gdy wszechwładna elita władzy łatwo poradziła sobie z chłopami i inteligencja, o wiele trudniej było zwyciężyć w tym ostatnim konflikcie ${ }^{13}$. Paradoks pierwszej i trzeciej form konfliktu polegał na tym, że to elita władzy uważała się za przedstawicieli klasy chłopskiej i robotniczej. Doświadczenia życia codziennego zdezawuowały tę ideologię i większość społeczeństwa polskiego czuła się oszukiwana przez elitę władzy, która zawsze była postrzegana jako klasa szczególnie uprzywilejowana, a nadto obcego pochodzenia. Stąd, jeśli nawet elita władzy straciła do końca swój mandat (zdobyty siłą), to zawsze jeszcze mogła liczyć na mocodawcę ze Wschodu, do czego zresztą się odwoływano, strasząc radziecką interwencją wojskową. Nadto komuniści zagwarantowali sobie ustawowo władzę poprzez uchwalenie ustawy o przewodniej sile PZPR.

13 W. Majkowski, People's Poland..., dz. cyt., s. 140-154. 
Powstanie „Solidarności” było ważnym krokiem w kierunku zmiany systemu. Chociaż wprowadzenie stanu wojennego opóźniło cały proces, to jednak nie odwróciło trendu. Nie oznacza to jednak, że sam proces był łatwy. Najpierw dlatego, że komuniści nie kwapili się do oddania władzy i na mocy ustaleń „okrągłego stołu” w sejmie kontraktowym zachowali większość. Pozwoliło im to kontrolować życie polityczne oraz uwłaszczyć się i zachować intratne państwowe stanowiska. Po drugie ekonomia polska była w bardzo złym stanie: szalała inflacja, brakowało na rynku podstawowych dóbr, państwo było ogromnie zadłużone...

Centralnym elementem transformacji systemowej w Polsce lat 90. był tzw. plan Balcerowicza ${ }^{14}$. Jako pierwszy krok plan zakładał ratowanie polskiej waluty - złotego, którego wartość oszacowano w styczniu 1992 roku na poziomie 9600 za jednego dolara. Dzięki funduszowi stabilizacyjnemu, który pozwolił na wpompowanie w polską gospodarkę potężnej sumy pieniędzy, pół roku później wartość polskiej waluty się ustabilizowała, a nawet złoty zyskał w stosunku do dolara (1 dolar - $9200 \mathrm{zł}$ ). Nie znajdowało to jednak żadnego odzwierciedlenia w stanie ekonomii, co powodowało galopująca wewnętrzną inflację - 70 proc. rocznie. Sztuczne utrzymywanie silnej waluty (jej siła nie wynikała z dobrej kondycji polskiej ekonomii) prowadziło do niekontrolowanego importu obcych towarów, niejednokrotnie dotowanych przez eksporterów. W takiej sytuacji

14 Autorem tego planu był nie Leszek Balcerowicz, a Jeffrey Sachs. Program zyskał aprobatę Międzynarodowego Funduszu Walutowego. Jego sposób wdrażania, jak również niektóre elementy budzą kontrowersje. O tym planie mówi Henryk Pająk, że „zmienił polską gospodarkę w masę upadłościową". Zob. H. Pająk, Piąty rozbiór Polski 1990-2000, Tomaszowice 1988, s. 50. 
produkcja w Polsce stawała się nieopłacalna, co powodowało lawinowy upadek zakładów i pojawienia się bezrobocia na niebywałą dotąd skalę. W pierwszym roku transformacji upadłych zakładów było 1 mln 126 tys. (6,1 proc.); w drugim - już 2 mln 156 tys. (11,4 proc.); W $1994-2$ mln 800 tys., a 2001 roku 3 mln 115 tys. (17,6 proc.). Dramatycznie obniżyła się wartość produktu krajowego brutto. I tak przyjmując za punkt odniesienia wielkość PBK w 1980 roku jako równą 100, w początkowych latach transformacji systemowej wynosiła ona: W 1990 - 96,1, W 1991 - 89,5, a w $1992-91,4^{15}$.

Konsekwencją takiego stanu rzeczy był spadek siły nabywczej dóbr i usług gospodarstw domowych. W jednym tylko roku (1990) ceny wzrosły o 650 proc., podczas gdy dochody w tym samym czasie wzrosły tylko o 500 proc.; w 1993 roku ceny wzrosły 29-krotnie w stosunku do roku 1989. Wzrost cen poszczególnych dóbr i usług był następujący: ceny żywności były 18-krotnie wyższe niż w 1989 $\mathrm{roku}^{16}$, usług 47-krotnie, energii cieplnej i gazu 116-krotnie, a energii cieplnej 229-krotnie ${ }^{17}$.

Zważywszy powyższe, nie dziwi fakt upowszechnienia się biedy w polskich rodzinach. Ekonomiczna bieda stała się doświadczeniem wielkiej liczby rodzin. W 1990 roku na granicy minimum socjalnego żyło w Polsce 33,8 proc. ludzi, w 1994 roku liczba ta wzrosła do 50 proc. „Zasięg ubóstwa poniżej granicy minimum socjalnego, który szacowano w 1989 r. na 14.8\% [...] w 1998 r. wzrósł do 49.8\%. Poniżej

15 „Rocznik Statystyczny” 1994, s. LXVII.

16 Materiały Ministerstwa Pracy i Polityki Społecznej 1995, cyt. za: Pełnomocnik Rządu ds. Rodziny i Kobiet, Raport o sytuacji polskich rodzin, Warszawa 1995, s. 22.

17 Materiały Ministerstwa Pracy i Polityki Społecznej 1995, cyt. za: Pełnomocnik Rządu ds. Rodziny i Kobiet, Raport o sytuacji polskich rodzin, dz. cyt., s. 40. 
minimum egzystencji żyło w Polsce w 1998 roku 5,6\% osób”"18. W 1999 roku, to jest 10 lat od początku transformacji systemowej, spadek poziomu życia w Polsce zadeklarowało 52 proc. ludzi, dla 26 proc. Polaków poziom życia się nie zmienił, a 22 proc. osób żyło się lepiej ${ }^{19}$.

\section{Cechy polskiej biedy}

Wydaje się, że po 25 latach transformacji systemowej cechy polskiej biedy niewiele się zmieniły. Polska gospodarka ustabilizowała się, a nawet oparła się kryzysowi ekonomicznemu, jaki dotknął ostatnio gospodarki światowe. Jednak nie przełożyło się to na znaczącą redukcję polskiej biedy. Uległa ona w pewnym sensie petryfikacji. Jest to niewątpliwie ściśle powiązane $\mathrm{z}$ największym problemem, z jakim polska gospodarka sobie nie radzi, a mianowicie z bezrobociem. Można zatem, bez większej obawy błędu, wiązać cechy polskiej biedy i biedy polskich rodzin z cechami polskiego bezrobocia ${ }^{20}$.

18 L. Beskid, O materialnym rozwarstwieniu społeczeństwa polskiego, [w:] Jak żyja Polacy?, red. H. Domański, A. Ostrowska, A. Rychard, Warszawa 2000, s. 217.

Minimum egzystencji jest definiowane jako „wartość koszyka żywności, odzieży chroniącej przez zimnem, podstawowej pomocy leczniczej oraz możliwie niskiej opłaty mieszkaniowej”. Zob. A. Ochocki, Zagrożenie trwatym ubóstwem rodzin i gospodarstw domowych $w$ Polsce, [w:] Rodzina polska u progu trzeciego tysiąclecia, red. W. Majkowski, Warszawa 2003, s. 33. Minimum socjalne to nie tylko koszt podtrzymania życia, ale także koszty wychowania dzieci czy podtrzymania więzi społecznych; minimum socjalne jest miarą godziwego poziomu życia.

19 L. Beskid, O materialnym rozwarstwieniu społeczeństwa polskiego, dz. cyt., s. 221.

20 Por. E. Tarkowska, Ubóstwo i wykluczenie społeczne. Koncepcje i polskie problemy, [w:] Wspótczesne społeczeństwo polskie. Dynamika zmian, red. J. Wasilewski, Warszawa 2006, s. 349-360. 
Według Witolda Turnowieckiego na początku XXI wieku struktura polskich rodzin według zamożności przedstawiała się następująco:

- 5 proc. rodzin to rodziny bogate; tę kategorię tworzyły rodziny prywatnych przedsiębiorców, dyrektorów firm, menadżerów;

- drugą kategorię (17 proc.) stanowiły rodziny zamożne; rodziny właścicieli małych punktów usługowych, ludzi z wyższym wykształceniem oraz kadry przedsiębiorstw;

- 40 proc. to rodziny stabilne - rodziny urzędników, pracowników wykwalifikowanych, bogatych rolników, części emerytów;

- trzecią kategorię - rodzin biednych - 32 proc. tworzyły rodziny rencistów, robotników niewykwalifikowanych, osób starszych;

- w skład ostatniej kategorii - rodzin ubogich (6 proc.) wchodziły rodziny wielodzietne, rodziny żyjących z zasiłków, popegeerowskie ${ }^{21}$.

Ubóstwo polskich rodzin ma kilka dość wyraźnych cech: często jest „dziedziczone”, w dużej mierze jest skoncentrowane na obszarach wiejskich, jest skorelowane pozytywnie z bezrobociem i wielodzietnością. W kwestii dziedziczenia biedy centralnym problemem jest rodzaj samorekrutacji kategorii ludzi czy rodzin ubogich. „Chodzi o międzypokoleniowe dziedziczenie ubóstwa i utrzymywanie się na tych samych pozycjach na stałe"22. Argumentem za tego rodzaju fenomenem byłoby stwierdzenie, że znaczący odsetek jednostek wywodzi się z rodzin, które przynależały do tej właśnie kategorii. Problemem jednak pozostaje skala samorekrutacji. W Polsce

21 W. Turnowiecki, Kondycja rodziny polskiej po 1989 roku, [w:] Dzietność kobiet polskich $w$ okresie transformacji ustrojowej, red. E. Frątczak, I. Sobczak, Warszawa 2000, s. 170.

22 H. Domański, Ubóstwo w społeczeństwach postkomunistycznych, Warszawa 2002, s. 92. 
W 2000 roku wielkość samorekrutacji osiągnęła poziom 12,2 proc. Najczęściej kategoria ta była zasilana niepracującymi $-48,8$ proc. i robotnikami niewykwalifikowanymi - 19,5 proc. $^{23}$.

Mechanizm powielania biedy jest prosty. Biedni rodzice nie są w stanie zagwarantować swoim dzieciom odpowiedniego wykształcenia, zwykle z racji swojego ubóstwa. Nierzadko też ta kategoria rodziców nie przywiązuje do wykształcenia swoich dzieci wystarczająco dużej wagi. Najważniejsze jest dla nich jak najszybsze usamodzielnienie się dzieci albo ich dokładanie się do budżetu rodzinnego. Ubóstwo rodziców może też stanowić nieusuwalną barierę w rozwijaniu talentów dziecka. Ten rodzaj kształcenia zawsze generuje koszty i jest czasochłonny. Brak determinacji rodziców w tej materii skutkuje brakiem stworzenia dziecku możliwości rozwoju i w konsekwencji awansu społecznego. Można pokusić się nawet o stwierdzenie, że od biednych rodziców dzieci „uczą” się biedy albo po nich biedę dziedziczą.

Cechą polskiego ubóstwa jest jego rejonizacja. Czasowo bieda była udziałem wielu mieszkańców prawie wszystkich regionów. Dobrym przykładem tego stanu rzeczy były Łódź, szereg miast śląskich czy tereny, na których zamykano pegeery. Był to czas początkowej restrukturyzacji, kiedy upadało bardzo wiele zakładów pracy... Jednak obecnie ubóstwo najbardziej dotyka tereny, na których utrzymuje się największe bezrobocie, tam też jest najwyższy odsetek osób, które mają dochód poniżej minimum egzystencji. Na początku XXI wieku poniżej minimum egzystencji żyło w Polsce 11,8 proc. ludzi: w województwie warmińsko-mazurskim 18,2 proc., w województwie

23 H. Domański, Ubóstwo w społeczeństwach postkomunistycznych, tabela 20. 
świętokrzyskim 15,2 proc., a w województwie podlaskim 15 proc. Natomiast najniższy odsetek tej kategorii osób był w Opolskiem 8,7 proc. ${ }^{24}$. Ciągle w Polsce utrzymuje się podział kraju na "Polskę A” $\mathrm{i}$ „Polskę B”. Na inny jeszcze aspekt rejonizacji biedy zwraca uwagę Elżbieta Tarkowska, a mianowicie chodzi o „enklawy w wielkich miastach, biedne sąsiedztwa i wydzielone biedne społeczności wiejskie"25. Wymienione wyżej miasto Łódź jest dobrym tego przykładem.

Polska bieda jest wysoce i pozytywnie skorelowana z bezrobociem. Oznacza to, że enklawy bezrobocia w Polsce zasadniczo pokrywają się z enklawami biedy. Stwierdzenie to wydaje się truizmem, oczywiście przy założeniu, że głównym źródłem utrzymania Polaków $\mathrm{i}$ ich rodzin jest praca najemna. A skoro nie starcza jej dla wszystkich, bieda jest jej oczywistą konsekwencją. Teoretycznie możliwa jest sytuacja, że posiadane oszczędności mogłyby być antidotum na biedę. Jednak zwykle tak nie jest. W Polsce jest niewielki odsetek rodzin, które mają tak znaczące oszczędności, by móc funkcjonować bez zasilania rodzinnego budżetu zarobkami za pracę. Nadto to najbiedniejsi, z racji wykonywanej przez nich pracy, są najbardziej narażeni na utratę pracy, czyli stanie się bezrobotnymi, oraz to w rejonach biedy o pracę jest najtrudniej. Stąd wskaźnik skrajnego ubóstwa $\mathrm{w}$ rodzinach z co najmniej jednym bezrobotnym w Polsce w 2005 roku wyniósł 14 proc. i zwiększał się o około 60 proc. wraz z kolejnym rokiem pozostawania bezrobotnego $w$ gospodarstwie ${ }^{26}$.

Polska bieda jest też pozytywnie skorelowana z dwiema kategoriami wiekowymi: ludzi młodych i starych. Chociaż sama bieda

24 GUS, Warunki życia ludności w 2004 r., Warszawa 2006, s. 196.

25 E. Tarkowska, Ubóstwo i wykluczenie społeczne..., dz. cyt., s. 353.

26 A. Ochocki, Zagrożenie trwatym ubóstwem rodzin..., dz. cyt., s. 38. 
dotyka te dwie kategorie, to jednak każdą z nieco odmiennych racji. Kategoria ludzi młodych doświadcza biedy z racji bezrobocia, to jest braku dla nich pracy. Nie pracując, nie mają dochodu, a to lokuje ich wśród biednych, niekiedy nawet skrajnie biednych. Fakt jest oczywisty. To wśród młodych ludzi jest najwyższy odsetek bezrobotnych - w kategorii wiekowej 15-24-40 proc.; tak więc polska bieda dotyka w dużej mierze ludzi młodych. Słusznie zatem zauważa Elżbieta Tarkowska, że „istniejące dane i liczne publikacje nie docierają do opinii publicznej, która uparcie sądzi, że w Polsce najbiedniejsi są ludzie starzy, renciści i emeryci” ${ }^{27}$.

Nie oznacza to, że bieda nie jest udziałem tej ostatniej kategorii ludzi i ich rodzin. Dwa są tego powody. Najpierw wiele rent i emerytur jest bardzo niskich, co jednoznacznie spycha ich beneficjentów do kategorii ludzi biednych. Poza tym to ludzie starsi i chorzy maja dodatkowe wydatki, których zwykle nie mają albo mają tylko w niewielkim stopniu ludzie młodzi. Są to wydatki związane z prywatnymi wizytami u lekarzy, wykupieniem leków, czasem kosztowna dieta... Jeśli do tego dodać też fakt, że kategoria ludzi starszych dynamicznie wzrasta, to nie może dziwić, że w 2006 roku 17 proc. osób w Polsce było zagrożonych ubóstwem. Duży udział w tej kategorii mają ludzie starzy.

Znaczącym korelatem biedy w Polsce jest wielodzietność. W 2004 roku odsetek osób w gospodarstwach domowych mających dochody poniżej minimum egzystencji w rodzinie z jednym dzieckiem wynosił 6,4 proc., a z dwojgiem dzieci - 9,7 proc., odsetek osób poniżej minimum egzystencji w gospodarstwach z trojgiem dzieci wynosił 21,4 proc., zaś z czworgiem i więcej dzieci - 40,1 proc. ${ }^{28}$.

27 E. Tarkowska, Ubóstwo i wykluczenie społeczne..., dz. cyt., s. 356.

28 GUS, Warunki życia ludności w 2004 r., dz. cyt., s. 197. 
Dlatego oczywisty jest fakt, że ryzyko chronicznego ubóstwa zwiększa się wraz liczbą niedorosłych dzieci: w porównaniu z rodzinami bezdzietnymi jest trzy razy większe w przypadku rodzin jednym dzieckiem i sześć razy w sytuacji rodzin z czworgiem dzieci ${ }^{29}$.

Bieda ogromnej liczby rodzin nabiera jeszcze większego wyrazu w świetle bogactwa kategorii rodzin bogatych (około 5 proc.) i superbogatych. Tych ostatnich jest znacznie mniej niż bogatych, ale ich bogactwo poraża. Dobrym tego przykładem są zarobki niektórych sportowców, menadżerów, dyrektorów firm... Na przykład: prezes ING BSK Małgorzata Kołakowska zarobiła w 2013 roku 3 mln 241 tys. zł; członkini zarządu ING BSK Justyna Kesler - 2 mln 145 tys. zł; członkini zarządu KGHM - Dorota Włoch - 1 mln 553 tys.; szefowa PGNiG - Grażyna P. 1 mln 512 tys., a Joanna Schmid, członkini zarządu Tauronu $-1 \mathrm{mln} 463$ tys. zł $^{30}$. Tego rodzaju zarobki nie mają merytorycznego uzasadnienia, a w państwie, gdzie tak wiele rodzin, zwłaszcza wielodzietnych, żyje na skraju ubóstwa, z punktu widzenia moralnego są niegodziwe i nie mogą być żadną miarą usprawiedliwione! Są one znakiem ustabilizowania się pazernego kapitalizmu.

\section{Zakończenie}

Społeczna stratyfikacja jest nieusuwalnym elementem życia społecznego. Trudno nawet wyobrazić sobie społeczeństwo bezklasowe. Racją tego stanu rzeczy jest fakt, że oprócz przyczyn społecznych

29 A. Ochocki, Zagrożenie trwałym ubóstwem rodzin..., dz. cyt., s. 38.

30 „Rzeczpospolita” 5 czerwca 2014, http://archiwum.rp.pl/artykul/1244447Panie-subtelne-w-walce-o\%C2\%Aokase.html (28.02.2016). 
istnieją nierówności ludzi pod względem zdolności, pracowitości, umiejętności oszczędzania czy przypadkowych zdarzeń, które przyczyniły się do ich sukcesu czy jego braku. Przyczyną biedy, a więc nierówności, może być też własna wina -i nierzadko tak bywa. Można się nawet zastanawiać, na ile funkcjonalna byłaby bezklasowa struktura społeczna. To natomiast, co wydaje się rzeczą niesprawiedliwą, to niebywałe rozwarstwienie, niczym nieuzasadnione.

W następstwie takiego rozwarstwienia nie może zatem dziwić fakt, że w społeczeństwie polskim istnieje znaczny stopień poczucia niesprawiedliwości, a odsetek ludzi mających takie poczucie wzrasta: w 1995 roku 80 proc. Polaków dostrzegało te wielkie różnice w dochodach w Polsce, w 1999 roku wielkość tej kategorii Polaków wzrosła do 93 proc. Nadto wzrósł odsetek tych, którzy wyrażają zdecydowaną dezaprobatę dla takiego stanu rzeczy (z 39 proc. w 1995 roku do 70 proc. 1999 roku¹ $)$, i tych, którzy oczekują od państwa zapewnienia jednostkom i rodzinom minimum socjalnego (z 84 proc. W 1995 roku do 92 proc. W 1999 roku $^{32}$ ).

31 J. Sikorska, Materialne warunki życia w Polsce w latach 90., [w:] Jak żyja Polacy?, dz. cyt., s.132.

32 J. Sikorska, Materialne warunki życia w Polsce w latach 90., dz. cyt., s.132, 133. 